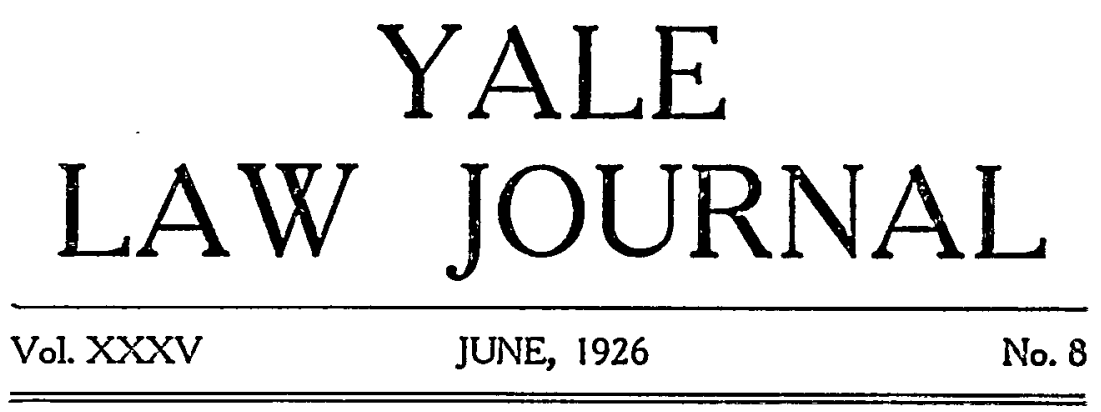

\title{
HISTORICAL DEVELOPMENT OF THE LAW OF BUSINESS COMPETITION
}

\author{
FRANKLIN D. JONES
}

The law of business competition springs from ancient sources. Centuries intervene between the days of barter and the modern epoch of vast industrial organization. The history of those centuries tells an interesting tale of the efforts of governments and courts to control the conduct of men in the rivalries of trade. Harsh repressive action, futile attempts by legislative fiat to stop the irresistible force of economic development and the operation of the law of supply and demand, government price fixing and licensing systems, public policies ranging from the most minute regulation to complete freedom from any governmental interference, are found in the law books of the centuries. The influence of the church, the writings of great economists, the ideas of powerful rulers, the dire necessities of starving masses of the people,-many divergent influences have together shaped the basic principles underlying the law of business competition. These principles were finally embodied in statutes and court decisions. To understand the legal rules governing modern competition we must not only look to two great sources of legal information, - the common law evolved by the courts and the statutory law as interpreted by them,--but also to the economic conditions which gave them birth. Throughout the law we find a steadily enlarging prohibition of two general classes of acts affecting competition. The first group have come to be known as monopolies and restraints of trade. The second group are those acts which the law calls unfair methods of competition.

The history of Anglo-Saxon peoples discloses an undying hostility toward monopoly. The records of ancient times recount the efforts of kings and judges to prevent monopolistic practices in local markets and fairs. As trade develops, we find the people struggling against the monopoly of local trade vested in the 
guilds of freemen in the towns. Still later, a hostile Commons backed by an irate public dares to stand against the imperious will of Queen Elizabeth in her efforts to establish national monopolies by grant to her court favorites. Then we see the great monopolistic trading companies organized to conduct the foreign trade of the nation forced out of existence by the demands of the people. Finally we witness the abolition of tariffs, bounties and similar devices designed to foster control of domestic industries and the establishment of free trade as a national policy. In the infancy of our existence as a sovereign nation, the principle of free, unrestricted competition was established as a basic policy in English trade and commerce.

\section{FORESTALLING THE MARKET}

Efforts to prevent monopoly and restraint of trade in the local markets appear in the earliest legal records of England. Between the twelfth and fourteenth centuries domestic trade was in large part carried on at fairs and markets. ${ }^{1}$ The markets were usually held once a week, and furnished a place where the produce and wares of the neighborhood could be bought and sold. The fairs which developed after William the Conqueror were great institutions held for periods varying from several days to a month. To them came Spaniards, Venetians, Flemings and merchants from every corner of Europe, with linens, silks, spices, furs, wines and all the luxuries of life. Fairs and markets could only be held by grant of the Crown. ${ }^{2}$ They afforded a safe place to trade, for both the King and the Church extended their protection to them. Thus in the charter granted by the KKing authorizing the fair at St. Ives appears those words, "I will and ordain that all who come to the fair, remain at it, and return from it, have my firm peace." 3

As most of the early grants were to religious bodies, the powerful protection of the Church was also secured. In fact so friendly was the Church, that buying and selling of merchandise often took place in the churches and their adjacent cemeteries, even on Sundays, to the great scandal of pious people. Lipson quotes from an ancient petition by folks, not so pious, who had held their meat market in the churchyard before service on Sunday, wherein they complained of their vicar who it seems one Sunday "in a very outrageous manner, ill-becoming a man of the church" had thrown the meat of a butcher on the ground "most pitiful to behold," had then threatened to kill the butcher even "if he hanged for it half an hour afterwards" and then to make life harder for his parishioners preached to them "in a most melan-

${ }^{1}$ Lipson, An Introduction to the Economic History of England (1915) chap. vi.

2 Coke, Institutes, $* 220$; Blackstone, Commentaries, 274 .

${ }^{3}$ Lipson, op. cit. supra note 1 , at 198. 
choly and angry vein" until they did "wish themselves at home." In an age when militarism was rampant, government was weal: and robbers infested the country, such centers naturally drew traders to them. No markets were permitted within sia and two-thirds miles of each other.:

Where the fair was held in a town the municipal authorities surrendered their authority during the life of the fair. Stalls were set up, and traders in the same commodity were grouped together, partly for the convenience of the buyers to promote competition. The fair had its own court, called the "pie powder court," or "court of the dusty feet" to assure prompt justice to merchants attending the fair." As trade slowly developed, these agencies offered to the King regular channels through which trade could be directed and regulated, and revenue secured. The owners of the markets or fairs usually exacted tolls on sales and a charge known as stallage for space for stalls in which to display goods. If they had a monopoly in specified territory their charges were often excessive. The obstruction of those coming to market so as to deprive the market owner of his stallage and the people of an unrestricted market in which to buy and sell, was called forestalling and was unlawful, both at the common law and under the statutes. At first the term seerns to have been applied merely to physical obstructions to the movement of goods to the markets; but the term quickly acquired a much larger significance. ${ }^{\circ}$ Naturally the absence of outside competition afforded great opportunity for the cornering or manipulation of local markets, particularly in seasons where there was a poor crop, and such efforts, when the lower classes were living under conditions of abject poverty, aroused bitter feeling. Early text writers emphasized the illegality of such practices.:

The oldest records of English laws show repeated efforts of the authorities to regulate practices designed to afiect prices. During the reign of Henry III, prices of corn rose to the unheard of price of $£ 1,4 \mathrm{~s}$. per quarter ( $\$$ bushels); prices of necessities fluctuated excessively; and many people died of starvation. ${ }^{\circ}$ An ancient chronicler alleges that in 1268 one hundred thousand poor people attended the feast of St. Edward at Westminster. ${ }^{9}$ Conditions became so bad that in 1266. a law lnowm as the "statute of the pillory and tumbrel and of the assize of bread and ale, and against forestallers" 10 was enacted. This statute, in addition

4 Bracton, f. 235 b.

5 Coke, loc. cit. sepra note 2.

- Illingworth, Forestalling (1S00) 10, 11.

'4 Bacon, Abridgment (Bouvier's ed. 1844) 385; Hawhins, Pleas of the Crown, chap. 80.

s Illingworth, op. cit. su:pra note 6, at 26.

9 Patent Rolls (1258-1266) 282.

10 (1266) 51 Hen. III, stat. 6. 
to fixing prices of various commodities, directed the leets,which were the local criminal courts,- to inquire as to forestallers, defining them as those "that buy anything before the due hour, or that pass out of towns to meet such things as come to the markets, to the intent they may sell the same in the town to regraters," and to punish transgressors in the town pillory. No doubt there were numerous local prosecutions under such a law, despite the fact that the power of the King was not then firmly established. It was at this time,- the reign of Edward I, - that national regulation of industry really began, although in an ineffective way. Several years after the passage of this law, one Wm. de Brewye, evidently a man of powerful local influence, was brought before the King and his court and fined for forbidding the men of the town of Shoreham to sell provisions to certain parties or to admit them to make purchases or sales in the town. ${ }^{11}$

In 1306, another law was enacted ${ }^{12}$ which provided that"No forestaller shall be suffered to dwell in any town, who manifestly is an oppressor of the poor, and a public enemy of the country, who meeting grain, fish, herring, or other things coming by land or by water to be sold, doth hasten to buy them before another; thirsting after wicked gain, oppressing the poor, and deceiving the rich; and by that means goeth about to sell the said things much dearer than he that brought them; who cometh about merchant strangers that bring merchandize, offering them help in the sale of their wares, and informing them that they may sell their wares, and that they meant to have done, and by such craft and subtility deceiveth a whole town and a country."

The punishment for the first offense was forfeiture of the goods, " for the second, the pillory, for the third, imprisonment and fine, and for the fourth, banishment.

An old writer ${ }^{13}$ indicates how bitter popular sentiment was toward those who attempted to manipulate the market. He says :

"Forestallers, ingrossers, and regraters, deserve to be reckoned amongst the number of oppressors of the common good and public weal of the realm, for they do endeavour to enrich themselves by the impoverishment of others, and respect not how many do lose, so they may gain. They have been exclaimed upon and condemned in parliament from one generation to another, as appeareth by the statutes $* * *$ but amongst others, especially by the statute $34 \mathrm{Edw}$. I, it was ordained that no forestaller should be suffered to dwell in any town; for he is a manifest oppressor of the poor and a decayer of the rich, a public enemy of the country, a canker, a moth, and a gnawing worm, that daily wasteth the commonwealth; and the act and name of a forestaller was so odious in that time, that it was moved in parliament to have had it established by law, that a forestaller should be baited

11 (1274) Mich. Term Y. B. 2 \& 3 Edw. I.

12 (1306) 34 Edw. I, stat. 5.

13 Pulton, De Pace Regis (1615) tit. Oppression. 
out of the town 'where he dwelt by dogs, and whipped forth with whips." "

Living conditions of the people at this time must have been deplorable. An old English writer, probably prone to exaggerate, describing conditions in 1314 says :

"notwithstanding the statutes of the last Parliament, the Kings Writtes, \&c., all things were sold dearer than before, no fleshe coulde be had, Capons and Geese could not be found, Egs were hard to come by, Sheepe died of the rot, Swine were out of the way; a quarter of wheat, beanes and pease were sold for 20 shillings, a quarter of MTalte for a mark, a quarter of Salt for 35 shillings." The following year "Horse flesh was counted great delicates; the poore stole fatte dogs to eate; some (as it was saide) compelled through famine, in hidde places, did eate the flesh of their owne Children and some stole others which they devoured. Theeves that were in prisons did plucke in pieces those that were newly brought amongst them and greedily devoured them half alive." 14

During this period as well as in previous years the government was compelled to fix prices. In 1314 on complaint of the college authorities at Oxford, the King fixed the prices of some necessities in that market. ${ }^{15}$ In 1330 , a law ${ }^{16}$ was passed prohibiting the sale of wines except at a reasonable price, taking into account their cost, and transportation expenses.

In 1348, there swept over England the terrible pestilence, known as the Black Death, which wiped out nearly half the population and wrecked the economic life of the country. Live stock likewise died in huge numbers. While prices fell to low levels in 1348, the tremendous shortage of laborers in following years, and the dearth of agricultural production immediately following, forced a great increase in prices. ${ }^{1 \tau}$ One ancient writer states that "what was worth a penny was now worth four or five times as much." 18 In 1349, during this plague, as it was impossible to get the members of parliament to meet, a regulation ${ }^{19}$ was adopted by a group of peers, bishops and leading men of the lingdom, which, in addition to making labor compulsory and fixing the wages of laborers, prohibited sales of victuals except at reasonable prices. The following year a statute was enacted ${ }^{20}$ providing that forestallers on conviction should forfeit the forestalled goods. A little later a law was passed making the forestalling of merchandise coming into a kingdom punishable by death."1

\footnotetext{
14 Stowe, Annals, cited in 1 Cunningham, Growth of English Industry and Commerce (5th ed. 1910) 388.

Is Illingworth, op. cit. supra note 6 , at 31 .

16 (1330) 4 Edw. III c. 12.

17 Ashley, Edward III and his Wars (1887) 123, 126.

182 Chronicon Knighton (Lumby's ed. 1889) 65.

19 (1349) 23 Edw. III c. 6; Illingworth, op. cit. sepra note 6 , at 32, 34 .

20 (1350) $25 \mathrm{Edw}$. III, stat. 4, c. 3.

21 (1353) $27 \mathrm{Edw}$. III, stat. 2, c. 11.
} 
In fixing reasonable prices the local magistrates were instructed to consider such factors as the price in adjoining places, the first cost of the goods, and the actual cost of transportation..$^{2 z}$

This statute and subsequent ones prescribing reasonable prices were in accordance with the teachings of the Church which held avarice and unreasonable profits to be a deadly sin. ${ }^{23}$ Ex-communication, invalidation of wills and other penalties were enforced by the Church against those who exacted exorbitant prices or practiced usury. The Ayenite of Inwyt, a manual for confessors, published in 1340 and widely circulated in England lays down these rules as to the evils of trade:

"The eighth bough of Avarice is chaffering, wherein one sinneth in many ways, for worldly winning, and, namely, in seven manners. The first is to sell the things as dear as one may, and to buy as good cheap as one may. The next is lying, swearing, and foreswearing, the higher to sell their wares. The third manner is by weights and measures and that may be in three ways. The first when one hath divers measures, and buyeth by the greatest weights or the greatest measures and selleth by the least. The other manner is when one hath rightful weights and rightful measures to sell untruly, as do the taverners that fill the measure with scum. The third manner is when these that sell by weight contrive that the thing that they weigh showeth more heavy. The fourth manner to sin in chaffering is to sell to time. Of this we have spoken above. The fifth manner is to sell otherwise than one hath showed before; as doth these scriveners that showeth good letter at beginning and after do badly. The sixth is to hide the truth about the thing that one will sell, as do the dealers of horses. The seventh is to contrive that the thing one selleth maketh for to show better than it is; as do the sellers of cloth that choose dim places wherein to sell their cloth. In many other manners one may sin in chafferings, but long time it were to say." 21

The law of the Church was studied in the law schools, and judges and statesmen were trained in its principles. That these principles should find expression in laws was inevitable.

The devastating effects of the pestilence were felt for years and many towns fell into decay. The period of high prices resulting from high wages and slack production, as well as the wars and debasement of money which took place in the reign of Edward III, naturally evoked legislation.

In 1363, the House of Commons petitioned the King, alleging that the forestalling and regrating of goods was causing exorbitant prices, and as a result the King issued a proclamation that the existing statutes should be put into effect and appointed a commission of inquiry. ${ }^{25}$ In 1370 one Nicholas Sardouch, a merchant of Lombardy, on petition of "the poor women called

\footnotetext{
221 Ashley, English Economic History (1893) 385.

23 Ibid. Chap. VI.

24 See Ashley, op. cit. supra note 17, at 70, 71.

25 Illingworth, op. cit. supra note 6 , at 41 .
} 
Silkewemen," was indicted at the common law for forestalling and regrating both raw and spun silk with the intent to raise prices. On trial by a jury of six natives and six foreigners, he was found guilty and fined $£ 200$ which in those days was an enormous sum..$^{26}$ Even the making of false statements designed to affect prices was unlawful. The engrossing of a commodity with an intent to sell it at an unreasonable price, was likewise held to be indictable at common law.: Similarly the engrossing of a commodity, such as malt, hops, or fish, and the sale thereof at an unreasonable price was held an offense at common law. This was a period of very heavy taxation because of the wars with France, and no doubt war brought considerable disruption of trade. Farm laborers were in a state of insurrection and the constant riots show the living conditions of the masses of people were very bad.9 In 1389 another law ${ }^{30}$ was enacted, providing that "Victuallers shall have reasonable gains, according to the discretion of the justices [of the peace]." This act express!y provided that punishment should be bodily and that the statute of $23 \mathrm{Edw}$. III c. 6 should be put in execution.

To us in these modern times, it is difficult to sense the living conditions of those times. The fifteenth century was one of pestilence and famine. There were twenty outbreals of plague during this one century. "The undrained neglected soil; the shallow stagnant waters which lay upon the surface of the ground, the narrow unhealthy homes of all classes of the people; the filthy neglected streets of the towns, the insufficient and unwholesome food; the abundance of stale fish which was eaten; the scanty variety of the vegetables which were consumed $\Rightarrow *$ predisposed the agricultural and town population alile to typhoidal diseases and left them little chance of recovery when stricken down with pestilence." 32

During the forepart of this century, there seem to have been some efforts made to prevent monopolistic practices. In 1411, the 12th year of the reign of King Henry IV, a special commission was directed to inquire and certify for prosecution all forestallers and regraters of corn. As a result the records show a number of men were indicted, although the final disposition of their cases does not appear. Such practices as buying in large quantities and selling at greatly increased prices, exporting to foreign countries, hoarding and refusing to sell except at ex-

\footnotetext{
26 Edw. III, Roll 19, cited in Illingworth, op. cit. supra note 6, at 235 .

2т See The King v. Mrayzard (1631) Croke Car. 231; 43 Edw. III, Roll 19, cited in Illingworth, op. cit. supra note 6 , at 235.

28 Roy v. Davies (1615) 1 Rolle, "11; Anon. (1649) Style, 192.

291 Cunningham, op. cit. supra note 14 , at 392.

so (1389) 13 Rich. II, stat. 1, c. S.

31 Denton, England in the Fifteenth Century (1888) 103.
} 
cessive prices, were termed forestalling under these indictments..$^{\text {ax }}$ It appears that frequent commissions were issued to locate and prosecute those guilty of forestalling or regrating. But there was no law enacted for many years regulating business competition. The towns where business had once flourished still felt the blight of the great plague. Portions of them had fallen into ruin. During the latter part of the century, Henry VII imposed such heavy taxes and duties that trade decreased. Wars, too, took their toll from industry. ${ }^{33}$

In 1532. Parliament enacted a law fixing the prices of meat." That this was a period of excessive prices is evidenced by the King's proclamation of this same year wherein it was stated that because of the great scarcity and high prices, and in order to prevent engrossing and regrating, the KKing's Council, or any seven of its members, should have the power to fix reasonable prices of all victuals necessary for man's sustenance, and providing for the forfeiture of goods sold at any other prices. . $^{30}$ Eight years later both these laws were repealed.30 During this same period, the woolen industry was becoming national in its organization and operation, but owing to the hostility of the weavers toward middlemen who purchased quantities of wool to meet the demands of large employers and exporters, Henry VIII tried to force trade back into purely local channels by the enactment of a law designed in part to prevent the engrossing of the commodity by middlemen. ${ }^{37}$

In the latter part of the fifteenth century, the town governments established a regular practice of purchasing corn in times of scarcity and retailing it at a reasonable price. Corn was imported from the continent and in this way the poor were better protected from the exactions of forestallers. Thus we read how the mayor of Bristol in 1522 when "whete, corn, and other graynes rose at a dire price" bought up large supplies so that the "inhabitauntes of the towne were greatly releved and comforted in mynysshing of the price of whete, corn, and other graynys sold in the open market." ${ }^{38}$

The poor laws adopted during this period show there were many unemployed and poverty was rampant..3 Legislative efforts were made to correct the situation, among them being the Weavers Act which among other things prohibited the ingross-

32 Illingworth, op. cit. supra note 6 , at 239.

331 Cunningham, op. cit. supra note 14, at 506.

34 (1532) 24 Henry VIII c. 3.

35 (1533) 25 Henry VIII c. 1, 2.

36 (1541) 33 Henry VIII c. 1.

37 (1545) 37 Henry VIII c. 15.

${ }^{38} 2$ Ashley, op. cit. supra note 22 , at $33,37$.

39 1 Cunningham, op. cit. supra note 14 , at 539. 
ing of looms, and the renting of them at unreasonable rates.83 In 1548 a law was passed ${ }^{21}$ prohibiting victuallers from conspiring to fix prices. For the first offense, the transgressor was to pay a fine of $£ 10$, or if such fine was not paid within six days, he was to suffer twenty days imprisonment on bread and water; for the second offense, he was fined $£ 20$ and for default in payment was compelled to stand in the pillory, and for the third offense, he was to be fined $£ 40$ and for default in payment was to stand in the pillory and lose one of his ears. This act was subsequently confirmed in 1670 by 22 \& 23 Car. II c. 19.

In 1549 , laws were enacted providing that no cattle should be bought except in open market, and prohibiting the buying of butter or cheese for resale except by retail in open shop market or fair. ${ }^{22}$ These statutes during this period seem to have been the result of very high prices existing during this time. In this same year, 1549, the King, on advice of the IKing's council, fixed prices of provisions under the old statute enacted during the reign of Hen. VIII. ${ }^{33}$ The following year the King prohibited the export of corn except at fixed prices, and authorized the justices of the peace in every county to inspect farmers' granaries, and after a jury had fixed the amount required by the owner for his own needs, to order the surplus brought to the next adjoining market. Fine and imprisonment were provided; but high prices still continued "by reason of conveyance of commodities beyond sea, and partly by men's buying up of corn in the markets to be sold again; and also by not bringing any quantities to the market," and the King issued yet another proclamation, dated September 24th, outlining in the preamble how the "infamous greediness of divers ill-natured people, neither minding the due obedience of good laws, nor any preservation of natural societies within their own country, and contrary to the provision of divers good laws and statutes, by frequent unlawful exportation of victuals, and by many detestible frauds and covins, had occasioned great scarcity and unreasonable prices of victuals," and therefore forbade exportation of grain except at certain fixed prices, prohibited the buying of various grains in the open market for resale and even provided for the forfeiture of goods, chattels, leases, and farms of farmers who evaded the law. But notwithstanding this "there came but little corn to the markets" and on the 20th of October the King, acting under the authority of the old statute, ${ }^{44}$ fixed the price of corn." ${ }^{45}$

\footnotetext{
40 (1555) 2 \& 3 Phil. \& MI. c. 11.

41 (1548) 2 \& $3 \mathrm{EdW}$. VI c. 15.

క2 (1549) 3 \& $4 \mathrm{Edw}$. VI, c. 19 ; c. 21.

43 See Illingworth, op. cit. supra note 6 , at $60 ; 2$ Strypes, Eccleciastical Memorials (1721) 151.

14 (1533) 25 Hen. VIII c. 1, 2.

45 2 Strypes, op. cit. supra note 43 , at 222.
} 
In this same year, 1550, was enacted the principal statute against forestalling, engrossing and regrating. This statute defines and prohibits forestalling, engrossing and regrating. It was unanimously passed by parliament. ${ }^{47}$

Forestalling was defined as follows:

"That whatsoever person or persons $* * *$ shall buy or cause to be bought, any merchandise, victual, or any other thing whatsoever, coming by land or by water toward any market or fair, to be sold in the same *** or make any bargain, contract, or promise, for the having or buying of the same, or any part thereof, so coming as is aforesaid, before the said merchandise, victuals, or other things, shall be in the market, * * * ready to be sold; or shall make any motion by word, letter, message, or otherwise, to any person or persons, for the enhancing of the price, or dearer selling of any thing or things above-mentioned, or else dissuade, move, or stir, any person or persons coming to the market $* * *$ to abstain or forbear - to bring, or convey, any of the things above rehearsed, to any market $* * *$ shall be deemed $* * *$ for a forestaller."

Regrating was defined as follows:

"That whatsoever person or persons $* * *$ shall by any means regrate, obtain, or get into his or their hands or possession, in a fair or market, any corn, or other commodities, that shall be brought to any fair or market within this realm "* " to be sold, and do sell the same again in any fair or market holden or kept in the same place, or in any other fair or market within four miles thereof, shall be ** * taken for a regrater."

Engrossing was defined as follows:

"That whatsover person or persons $* * *$ shall engross or get into his or their hands, by buying, contracting, or promisetaking, other than by demise, grant, or lease of land or title, any corn growing in the fields, or any other corn or grain, butter, cheese, fish or other dead victuals whatsoever, within the realm of England, to the intent to sell the same again, shall be accepted, reputed, and taken an unlawful engrosser."

For the first offense punishment of two months and forfeiture of the goods bought was provided; for the second offense imprisonment for six months and loss of double the value of the goods so bought was specified; for the third offense the culprit was to be placed in the pillory, forfeit all of his goods, be committed to prison and to remain there during the King's pleasure. Various exceptions were made to the act. Parties could buy grains for conversion into food in their own homes, or tradesmen could buy such necessities for use in their trade, if resold at retail and at reasonable prices. Innkeepers could buy grains for use in their establishments, or for resale at retail, if sold at reasonable prices, and various other similar exceptions were made, the obvious purpose of the act being to prevent any manipulations of

40 (1552) 5 \& 6 Edw. VI c. 14.

47 See Illingworth, op. cit. supra note 6 , at 67 . 
the market to control or enhance prices. During the next several years, several statutes were passed against these and similar practices. ${ }^{18}$ There were also numerous town ordinances adopted prohibiting forestalling. ${ }^{40}$

While wars, the debasement of the coinage, and the decay of agriculture due to the shift to sheep grazing were no doubt the chief factors bringing about high prices during this period there was a general feeling at the time that they were due to combinations in restraint of trade. The very poor methods of transport of course made it very easy to secure a "corner" in local marliets and probably numerous instances of this sort furnished apparent proof that they were the cause of the general high level of prices. A proclamation issued by the King in 1551 complains of the scarcity of provisions.

Twelve years later in 1562 during the reign of Queen Elizabeth, a law was passed which, after stating the inconvenience to the public from the great number of drovers of cattle and badgers of corn and other victuals, whose activities enhanced prices, provided that such persons must be licensed in open sessions of the peace; that such persons must have dwelt in their localities three years; must be married men, householders, at least thirty years of age, and that such license should be granted only for one year, and provided that they should give bond with surety that they would not forestall or engross commodities in violation of the law. ${ }^{50}$ This law and many local regulations were devised to prevent the monopolization of local supplies, particularly of corn, so as to protect the poor consumer. In some localities, dealers could not buy until the poor had made their purchases.

That this condition continued is indicated by the proclamation of Queen Elizabeth in 1586, wherein she spealis of the dearth of food, and the "covetousness of many engrossers of corn" and threatened to severely punish offenders who violated the statute enacted in the reign of her father, Henry the Eighth, which prohibited the charging of unreasonable prices. ${ }^{51}$ By the middle of the following year, the Queen again issued a proclamation condemning engrossers and others who "do pretend to raise the prices by colour of the unreasonableness of this Summer" to the "Griefe of her poorer sort of people" and who of "meere covetousness have very lately even within two months, most uncharitably haunced up their prices, not tollerable to be suffered." $: 2$ The justices were ordered to take such action as would reduce prices.

48 (1552) 5 \& 6 Edw. VI c. 15; (1554) 1 \& 2 Phil. \& M. c. 7.

13 (1552) Lipson, op. cit. supra note 1 , at 272.

so (1562) 5 Eliz. c. 12.

51 Dyson, Proclamations of Qucen Elizabcth (1618) 241; ef. 2 Cunningham, Growth of English History and Commerce (3d ed. 1903) 92.

s2 2 Cunningham (1912) op. cit. supra note 14, at 98; Dyzon, op. cit. supro note 51 , at 338 . 
For a period of several years good crops brought low prices to consumers but during the period between 1593 and 1597 there was a great scarcity and the supply of food in many localities was insufficient. ${ }^{53}$ There was also at this time intense popular feeling against national monopolies which had been granted by the Queen to court favorites. Beginning in 1604 several more statutes were enacted dealing with forestalling and similar practices as applied to particular commodities..$^{54}$ That there was widespread complaint against local monopolies of this character is evidenced by the following statement in the journal of the House of Commons in $1604: 55$

"All the clothiers and in effect all the merchants of England complained grievously of the engrossing and restraint of trade by the rich merchants of London, as being to the undoing or great hindrance of all the rest."

In 1618 the government increased its control by a proclamation vesting in the clerks of the markets broad powers of regulation. These clerks were local officials who punished all market offences. By this proclamation the clerks were directed to fix reasonable prices of victuals and other provisions and "especially to inquire of, and punish all Forestallers, Engrossers, and Regrators who by their inordinate desire of gaine do enhance the prices of all things vendible." ${ }_{50}$ In 1622 the clothing trade, the great industry of the country, was stagnant and there was widespread suffering and unemployment. ${ }^{57}$ Evidencing the serious conditions existing at the time was the proclamation of the King, issued in 1623. By the proclamation the King, observing that in times of scarcity the poorer classes were in great want of provisions, and that in times of plenty farmers by the low prices and lack of demand for their corn were unable to support their expenses, established public magazines and empowered merchants to erect storehouses for storing English corn which they might buy in such quantities as they saw fit whenever certain specified grains sold below the prices named in such proclamation. For many years the larger cities had been compelled to import quantities of corn from the continent and store it for the protection of the poor in times of scarcity. ${ }^{58}$ The prohibition of forestalling and regrating, discouraging as it did the wholesaling of goods, made such action well nigh essential. That there was a great deal of local cornering of supplies is indicated by a seventeenth century

\footnotetext{
53 2 Cunningham, op. cit. supra note 14, at 101.

54 (1604) 2 Jac. I, c. 22, sec. 7; (1605) 3 Jac. I, c. 9, sec. 3.

55 (1604) I The Journals of the House of Comimons, 218.

${ }^{56} 2$ Cunningham, op. cit. supra note 52, at 94.

57 Ibid. 507, 233.

58 Lipson, op. cit. supra note 1 , at 273.
} 
writer who complains that in his time "these monopolists began to swarm like the frogs of Egypt." :s

Because of the high prices prevailing at this time, Charles the First was compelled to issue proclamations in 1630 regulating the prices of certain foods, and again in 1638 the Fing issued a proclamation regulating the prices of rabbits, butter, poultry, candles, fuel and some other commodities. ${ }^{60}$ From this period on to 1700 , there were several statutes enacted bearing upon marketing methods. ${ }^{32}$

During the reigns of Elizabeth and Charles I, the regulation of trade had been under the administrative control of the Privy Council. The flexibility of the system made it react quickly to changing conditions and there seems to have been a sincere effort to protect the poor consumer, who lived under conditions of desperate poverty, against local monopolies and restraints of trade in absolute necessities of life. But early in the eighteenth century, Parliament secured control of the government. A legislative body acts slowly and can deal effectively only by the adoption of general measures. Eribery by business organizations seeking special privileges was not unknown in the House of Commons. ${ }^{62}$ At the same time various factors contributed to the establishment of prosperity in the country. Foreign trade was developing rapidly. The establishment of the Bank of England popularized paper money, organized the capital of the nation, made it available in trade, greatly widened the use of credit, and thus stimulated business in all its forms. ${ }^{63}$ The increase of trade of course increased the demand for labor. For the first half of this century there was no legislation, and probably no need for it since the laws then in existence seem to have been but little invoked. In 1757, however, there was a great scarcity of food and prices were fixed for bread, oatmeal and other cereals. ${ }^{\mathrm{ct}}$ In 1766, the prices of necessities were so high that there were uprisings among the poorer classes of people. Corn was seized, flour mills destroyed and as a result a proclamation was issued in September of that year stating the laws against forestalling were still in effect. ${ }^{\circ 5}$ From 1765 to 1774 the weather was bad and crops poor, and for some years thereafter the seasons were very irregular, thus producing great fluctuations in prices, which

59 Hearnshaw, Leet Jurisdiction (1908) 114; see Lipson, loc. cit. supro note 58.

co Illingworth, op. cit. supra note 6 , at 80.

61 Scobell, Acts of Parliament (1658) Part II, 142; (1663) 15 Car. II c. 7, sec. 4 ; ibid, c. 8 ; (1670) $22 \& 23$ Car. II, c. 19 ; (1700) 11 \& 12 Will. III, c. 13 , sec. 5 .

622 Cunningham, op. cit. supra note 14 , at 404 .

e3 Ibid. 442.

6s (1758) 31 Geo. II c. 29.

65 Cf. Girdler, Permicious Consequences of Forestalling, Regrating and Engrossing (1800) 23. 
not only ruined small farmers but also induced widespread speculation. ${ }^{6}$ Many complaints were at different times presented to Parliament, alleging that existing high prices resulted from. forestalling and similar practices, which complaints were referred to parliamentary committees for investigation. But the organf ization of trade had long since progressed far beyond the simple trade and barter of the markets, fairs and towns. Business was becoming organized on a national scale, and foreign trade had come to be of great importance. Improved transportation had freed local communities from the danger of local famines or monopolies, and these laws designed to deal with conditions arising under the old organization of business were not only obsolete but in fact hampered the free movement of goods, which would make the supply fluid and equalize prices. Thus they tended to create the very conditions they were designed to prevent. Adam Smith in his great book, The Wealth of Nations, condemned such laws in most vigorous language. "The popular fear of engrossing and forestalling" said he "may be compared to the popular terrors and suspicions of witchcraft." 67 The Parliamentary committee appointed to investigate the matter reported in the following language:

"1. That it is the opinion of this committee that the several laws relating to badgers, ingrossers, forestallers, and regrators, by preventing the circulation of, and free trade in corn and other. provisions, have been the means of raising the price thereof in many parts of this kingdom.

2. That it is the opinion of this committee that the house be moved to bring in a bill to remedy the evils occasioned by the said laws." "8

No action was taken for several years. Further complaints were made to Parliament from different sections of the country, urging a better regulation of the markets; but after further investigation the committee made a report urging a repeal of these laws; and in 1772 a statute was enacted intended to repeal these various statutes. Probably through defective draftsmanship a number of these laws were not included in this repeal.

This law which recognizes the tendency of the previous restrictions in fact to restrain trade, reads as follows:

"Whereas it hath been found by experience, that the restraints laid by several statutes upon the dealing in corn, meal, flour, cattle, and sundry other sorts of victuals, by preventing a free trade in the said commodities, have a tendency to discourage the growth and to enhance the price of the same; which statutes, if put in execution, would bring great distress upon the inhabitants of many parts of this kingdom, and in particular upon those of

${ }^{60} C f$. Cunningham, op. cit. supra note 14, at 560 .

or 2 Smith, An Inquiry into the Nature and Causes of the Woalth of Nations (1776) Book iv, ch. iv.

os Illingworth, op. cit. supra note 6 , at 89. 
the cities of London and Westminister; be it therefore enacted. . . That the act of $3 \& 4 \mathrm{Edw}$. VI. c. 21, concerning butter and cheese; the 5 \& 6 Edw. VI c. 14 against regrators, forestallers, and ingrossers; 3 Ph. \& MIary, c. 3, respecting milch kind, etc.; 5 Eliz. c. 12 touching badgers of corn, and drovers of cattle to be licensed; 15 Car. II. c. 8 , to prevent selling of live fat cattle by butchers and so much of the stat. 5 Anne, c. 34, as relates to butchers selling cattle alive or dead in London and Westminister or within ten miles thereof; and all acts made for the better enforcement of the same being detrimental to the supply of the labouring and manufacturing poor of this kingdom, shall be and the same are hereby declared to be repealed." 63

Thus the term forestalling, as years passed by, acquired a very broad meaning. Illingworth, an English lawyer who made a thorough investigation of the law in 1800, defined it as follows:

"Forestalling, commonly speaking, means, to market before the public, or, to anticipate or prevent the public market; but, legally understood, it has a greater signification, for it comprehends all unlawful endeavours to enhance the price of any commodity, and all practices which have an apparent tendency thereto, such as, spreading false rumours; buying commodities in the market before the accustomed hour; buying and selling again the same articles in the same market; and other such criminal devices. It also comprehended the offences of regrating and ingrossing; but the names regrator and ingrosser were not lnown before the reign of Hen. III. 3 Inst. 195, 196-1 Hawk. P. Cor. c. 80-Brown Indict. $40-$ Cromp. p. 80 b. No attempt of this lind can be looked upon in any other light than as an offence against the public, as it apparently tends to put a check upon trade to the general inconvenience of the people, by putting it out of their power to supply themselves with any commodity, unless at an unreasonable expense; which often proves extremely oppressive to the poorer sort, and cannot but give just cause of complaint even to the richest. Hawkins, P. C. $234.0^{\circ 0}$

Miost of these laws dealt with farm products, and were designed to protect consumers but their enforcement by preventing freedom of distribution has often created a shortage in one locality and an oversupply in another. Their repeal therefore was wise. Both the public and the courts, however, remained opposed to monopoly and the manipulation of the market, and in 1800 it was held that the common law was still in force against such offences as forestalling and engrossing..$^{71}$ In this case the spreading of false rumors that there would be a shortage of the crop of hops, for the purpose of inducing growers to withhold their supply from the market and thus enhance prices, was declared unlawful.

Thus for five centuries the English people struggled against local monopolies and practices restraining trade primarily in the

(1772) 12 Geo. III c. 71.

3 Illingworth, op. cit. supra note 6, at 14; see also Eurns, Justice (11th ed. 1769) 195.

is The King $i$. Waddington (1801) 1 East, 148, 
products of the farm until they built up a substantial body of prohibitions. But most of these rules were designed for a system of trade based upon the limited, localized trade of the towns and markets, while commerce even in farm products had become national in its operation. As the forces of competition became unleashed by improvements in transportation, credit and banking, and fostered by the security of person and property guaranteed by a strong government, the danger of local monopolies was largely removed and these preventive measures directed at them became largely obsolete and in fact restrictive of competition. Price fixing, licensing systems, and even extremely severe penalties failed to prevent the irresistible development of industry and trade on a national rather than a local basis. The power of the common law however to reach harmful monopolies or efforts to control the larger markets remained unimpaired.

\section{AGREEMENTS TO REFRAIN FROM PRACTICING A TRADE}

Another class of restraints given considerable attention by the common law courts in mediaeval times was that involved in agreements with reference to the practices of one's trade. The production of manufactured goods was entirely by skilled artisans and their apprentices, who were organized in gilds in the towns. As there were many regulations restricting a man's right to enter a trade, to move from his own town, or to engage in any trade but his own, any agreement made by him not to practice his own trade became of real importance to his community, for such an agreement might have the effect of making him and his family a charge upon the community as well as depriving the community of the benefit of his competition. In 1415, in a suit brought on a bond entered into by a dyer that he would not engage in his trade, the bond was held unlawful and the judge vociferously exclaims, "By God! if the plaintiff were here, he should go to prison, till he paid a fine to the king." 72

The reasons why agreements in restraint of trade were held illegal at common law is stated by an early Massachusetts court in the following language:

"The unreasonableness of contracts in restraint of trade and business, is very apparent from several obvious considerations. 1. Such contracts injure the parties making them, because they diminish their means of procuring livelihoods and a competency for their families. They tempt improvident persons, for the sake of present gain, to deprive themselves of the power to make future acquisitions. And they expose such person to imposition and oppression. 2. They tend to deprive the public of the services of men in the employments and capacities in which they may be most useful to the community as well as themselves. 3. They discourage industry and enterprise, and diminish the products of

${ }^{2}$ Case of Joln the Dyer Y. B. (1414) 2 Hen. V, 5, pl. 26. 
ingenuity and skill. 4. They prevent competition and enhance prices. 5. They expose the public to all the evils of monoply." $: 3$

But as business developed and the value of good will became understood, as individual freedom of movement and action was secured, and as corporations became factors in trade and commerce, the courts began to relax their position and to determine from the particular facts of each case whether the restraint was in fact unreasonable.

Judge Taft has described the development of the law in this respect in the following succinct language:

"The inhibition against restraints of trade at common law seems at first to have had no exception. See language of Justice Hull, Year Book, 2 Hen. V., folio 5, pl. 26. After a time it became apparent to the people and the courts that it was in the interests of trade that certain covenants in restraint of trade should be enforced. It was of importance as an incentive to industry and honest dealing in trade, that, after a man had built up a business with an extensive good will, he should be able to sell his business and good will to the best advantage, and he could not do so unless he could bind hinself by an enforceable contract not to engage in the same business in such a way as to prevent injury to that which he was about to sell. It was equally for the good of the public and trade, when partners dissolved, and one took the business, or they divided the business, that each partner might bind himself not to do anything in trade thereafter which would derogate from his grant of the interest conveyed to his former partner. Again, when two men became partners in a business, although their union might reduce competition, this effect was only an incident to the main purpose of a union of their capital, enterprise, and energy to carry on a successful business, and one useful to the community. Restrictions in the articles of partnership upon the business activity of the members, with a view of securing their entire effort in the common enterprise, were, of course, only ancillary to the main end of the union, and were to be encouraged. Again, when one in business sold property with which the buyer might set up a rival business, it was certainly reasonable that the seller should be able to restrain the buyer from doing him an injury which, but for the sale, the buyer would be unable to inflict. This was not reducing competition, but was only securing the seller against an increase of competition of his own creating. Such an exception was necessary to promote the free purchase and sale of property. Again, it was of importance that business men and professional men should have every motive to employ the ablest assistants, and to instruct them thoroughly; but they would naturally be reluctant to do so unless such assistants were able to bind themselves not to set up a rival business in the vicinity after learning the details and secrets of the business of their employers." is

${ }^{73}$ Alger v. Thacker (1837, Mass.) 19 Pick. 51, 54.

7 United States i. Addyston Pipe \& Stecl Co. (189S, C. C. A. 6th) 85 Fed. 271, 280; (modified on other grounds in (1899) 175 U. S. 211, 20 Sup. Ct. 96). 


\section{THE GILD MONOPOLIES}

In early mediaeval England, the town and village were the centers of business life. Trade was local rather than national and there were in fact comparatively few towns. At the time of the Norman Conquest there were only eighty towns in England and the total town population was probably not over one hundred fifty thousand..$^{75}$ In the absence of national regulation, some sort of organization was necessary to regulate the conduct of trade within the towns. As early as the eleventh century we find records of charters granted to so-called merchant gilds. ${ }^{\circ 0}$ The merchant gilds were organizations of traders to whose members were granted by the Crown the exclusive right to buy and sell commodities other than food either at wholesale or at retail without payment of customs or tolls within the town or territory covered by the charter given to them.77 For example in the charter to the gild at Oxford it is provided that "none who is not of the gild shall do any traffic in the city or suburbs." is They were thus given a commercial monopoly within their particular territory. In most towns this monopoly was not exercised fully because such a policy was contrary to the selfish interests of gild members, and non-members were therefore permitted to buy and sell at wholesale provided they paid toll and sold only to members of the gild, and did not buy a few specified commodities of which there was no surplus. ${ }^{\text {99 }}$ But the most strenuous efforts were made to prevent retail competition by foreigners and these were for a long time successful.so The gild had elective officers, adopted regulations, possessed a court and provided the machinery for the regulation of the trade controlled by it. As its membership included many of the burgesses, who possessed the voting power, it often exercised a large control over the policies of the municipal governments which tended strongly to protect its monopolistic privileges. In their early development the merchant gilds served a most useful purpose. The national government was weak. It could not effectually regulate trade and the constant wars increased its need for revenue. An organization such as the gild afforded a means for regulation and a source of revenue, for such organizations had to purchase their privileges from the King or the lord of their locality outright or by the annual payment of money or both. And they did not buy such rights cheaply from high living, ambitious monarchs. While in fact monopolies, they did

is 1 Ashley, op. cit. supra note 22, at 68.

io Lipson, op. cit. supra note 1, at 240.

71 Cunningham, op. cit. supra note 14, at 219.

781 Riley, Liber Custumamin (1860) 671; Lipson, op. cit. supra note 1, at 241.

:0 Lipson, op. cit. supra note 1, at 241.

801 Cunningham, op. cit. supra note 14, at 249. 
not at first show the evil tendencies of monopolies, for the financial burdens placed upon them made them anxious to secure every trader in their membership. But membership carried with it very valuable privileges. In most gilds each member was required to share his bargains with other rnembers present when the purchase was made. This so-called right of "lot" of course forced the more skillful buyers to share the benefits of their shill with other members, and naturally largely eliminated competition in bidding with results probably not entirely pleasant to the seller. The officers of the gild likewise made purchases for their members, known as "common bargains." 81 An outsider bringing a quantity of merchandise for sale would be compelled to deal with such officers if at all. In this way he was denied the benefit of this bidding competition and the members secured the goods at advantageous prices. Members were aided by the gild in time of adversity. Arbitration of all disputes between members was compelled."2 Then his business took him to other towns he had behind him the prestige of his gild to protect his person and property against unreasonable action. ${ }^{83}$ From the public standpoint, the gilds performed an invaluable service by maintaining high standards of quality and worlemanship which for many years were rigorously enforced. In the middle ages when religious teaching made it wicked to charge an unreasonable price it is probable the gilds did not at first abuse this power to fix: prices. In fact their membership was so diversified that differing interests did not make them the most effective agencies for fixing high prices.

But during the fifteenth and sixteenth centuries the gilds fell into decay and gradually became a negligible factor in the economic life of the country. Various causes contributed to this result. Their monoply of trade within their own town and their rigorous efforts to protect it forced trade away and undermined their prosperity. ${ }^{\text {st }}$ Again the towns in which the gilds were located depended to a great extent upon trade from contiguous territory, and they were thus compelled to meet the competition of the fairs and markets which attracted the same buyers and sellers. Likemise the policy of the Crown in granting, for sufficient compensation, immunity to tolls to the inhabitants of different towns, ecclesiastical orders and others, tended to break down the monopoly of town trade held by the gilds, and to develop more widespread commercial intercourse throughout the nation. ${ }^{85}$ The compelling necessities of trade, if business were to develop, forced the adoption of inter-municipal treaties giving reciprocal

\$1 Ibid. 245; 2 Ashley, op. cit. supra note 22, Part II, 39.

\$2 2 Gross, Gild Merchant (1890) 65.

s3 Lipson, op. cit. supra note 1 , at 246.

s4 1 Gross, op. cit. supra note 82 , at 52.

85 Lipson, op. cit. sipra note 1, at $\mathbf{2 5 6 .}$ 
rights of exemption from tolls to the burghers of the towns parties to them who came to trade, and thus led to greater freedom..$^{80}$ Similarly they were gradually forced to meet foreign competition. When controlling the city governments, the gilds procured ordinances requiring foreign merchants to buy only from their members and to sell solely to them, to deal only at wholesale, to remain in the country only a short period, and in various other ways restricting them. But the great lords who wanted to sell their agricultural products direct to the foreigners and to buy direct from them, after a long period of opposition finally procured the removal of such restrictions from a sympathetic King who saw in the foreign merchants an additional source of revenue. ${ }^{g r}$ These foreign merchants, organized in powerful associations, became very strong competitive factors in breaking down the monopolies of the gilds. Such monopolies in a great distributing center such as London early evoked hostile sentiment, for they compelled every Englishman from the country who brought goods for sale to foreign buyers, to make his sale through a London merchant, or run the risk of forfeiting his goods. In 1405 public feeling against such a curtailment of freedom to trade compelled the enactment of a law permitting all merchants in London to carry on wholesale dealings with any of the King's subjectsss although the retail monopoly was of course still retained.

Likewise it is evident the gilds lost popular support. In order to evade their regulations and the heavy burden of taxation placed upon them, tradesmen went into the country districts, or to new towns, so that there grew up a large body of business men unfriendly to them, and who could sell more cheaply because they were freed from the burdens borne by a gild member. The gild efforts to fix prices at excessive levels, and the methods employed to control them excited hostility. In an old English case in 1397, a merchant complained that "because he sold his merchandise at a less price than other merchants of the town of Yaxley did there *** they assaulted him, beat him and ill-treated him and left him there for dead, so that he despaired of his life." 80 As the common people made their demands felt, the municipal governments acquired partial control over the gilds. The old records show the great difficulty encountered in holding down prices. Often the officials were bribed. Often they were themselves members of the gild. In fact it may be said that the officials of the towns were almost entirely members of the gild, their gild hall being often used as the town hall.00 That the

se 2 Ashley, op. cit. supra note 22 , at 44 .

87 Ibid. Part I, 105; Part II, 13.

88 (1405) 7 Henry IV, c. 9; 1 Ashley, op. cit. supra note 22, Part II, at 16.

89 Select Cases in Chancery (Selden Society, 1896) 28.

${ }^{00} 1$ Cunningham, op. cit. supra note 14, at 225. 
common people sometimes expressed their feelings plainly, is evidenced by an old record which tells how in the city of Coventry "the commons rose and threw loaves at the mayor's head in St. Mary's Hall, because the bakers kept not the assize, neither did the mayor punish them according to his office." or The history of the towns shows the efforts of some town officials, however, to prevent the exaction of excessive prices. Such action could only have resulted from the most vigorous demands of the masses of people who lived under conditions of deplorable poverty. It is not improbable also that as the national government became strong, its comparative freedom from local influence in the administration of regulations deprived the merchant gilds of much of the benefit which would have otherwise acerued from their control of the town governments and their monopoly of trade.

Another potent factor tending to destroy the merchant gilds was the tendency of their members to withdraw and form more specialized organizations devoted to the interests of a particular trade or craft. The merchant gilds, like our modern chambers of cornmerce, were composed of a most diversified membership. ${ }^{02}$ As in the modern organizations so in the old, interests so often clashed that their effectiveness was often seriously impaired. As industry and trade developed, the interests of producers of competitive products, of manufacturers and distributors, of employer and artificer clashed and there rapidly developed the picturesque organizations known as the craft gilds. The new organizations were really modeled on the old, and their general development was about a century subsequent to that of the merchant gilds. ${ }^{23}$ The old spirit of monopoly still prevailed, but each gild secured control of the monopoly of its own particular trade or craft. Parliament, moreover, by a law enacted in 1363 provided that "artificers and men of mysteries shall each join the craft he may choose between this time and the next Candlemas" and prescribed a penalty of fine and imprisonment for failure so to do. ${ }^{34}$ So there came into existence gilds of Armourers, Haberdashers, Fishmongers, Goldsmiths, Tailors, Cappers, Cobblers, Pewterers, Cordwainers, Bakers and what not. The old merchant gilds were probably in large part organizations of merchants. The new craft gilds were really in the main organizations of petty manufacturers. Later after a bitter fight they came under the control of the municipal governments, and were as a general rule created by the town authorities. ${ }^{55}$ Often their monopolies were bought of impecunious monarchs, and they customarily paid an annual sum

91 Lipson, op. cit. supra note 1 , at 269.

921 Cunningham, op. cit. supra note 14, at 344 .

93 1 Ashley, op. cit. sitpra note 22, at 76.

94 Ibid. 95.

as Lipson, op. cit. supra note 1 , at $339 ; 1$ Cunningham, op. cit. supras note 14, at 337 . 
either to the national or municipal government for their monopolistic franchises. In the beginning, all persons practicing the trade were required to become members, for the heavy price paid for the monopoly required a large membership to carry its burden. They were in fact quasi-governmental bodies exercising very important powers..$^{96}$ They were required each year to. put on costly plays and pageants, generally of a religious nature, which ultimately became a severe drain on their financial resources, but which expense was strongly urged as a justification for their monopoly.97 They often supported altars and priests in the local church. They contributed to the support of poor members, even building almshouses "for the brethen of the livery or clothing falling into poverty." 98 They often maintained schools. But their main purpose was of course to control their trade and in the regulation of business when trade was localized and national government weak, they performed an invaluable service. The gilds thus regulated the quality of the product and inflicted penalties for inferior workmanship, and fraudulent trading. ${ }^{00}$ They established rules for apprenticeship to assure a supply of expert workmen. They adopted rules against unfair competition by one member against another and for "the abating of all guiles and trickery." 100 They maintained a compulsory system of arbitration of disputes between their members. Their control over their members was so strict that in some cities they could fine, place in the stocks or imprison members for violation of their rules. They regulated wages. It seems probable, too, that at first, in response to the religious teachings of the times, they fixed prices on a reasonable, fair basis. But as time passes their methods changed. There are records of court proceedings against gilds going back as far as the fourteenth century for agreements or conspiracies to fix prices. ${ }^{101}$ The ecclesiastical courts were utilized to aid in a curious way in enforcing such agreements. In 1344, a purser complained that the members of his gild bound him by oath not to sell below a fixed price, and on his failure to keep his oath brought him before the church court for perjury. ${ }^{102}$ Constant complaints from 1320 on were made of the monopoly

${ }^{90}$ For a complete discussion of the craft gild, see Lipson, op. cit. supret note 1, Chap. VIII.

9i 2 Ashley, op. cit. supra note 22 , at 78.

os 1 Clode, Early History of the Merchant Taylors Company (1888) 3.

931 Ashley, op. cit. note 22, at 90.

1001 Cunningham, op. cit. supra note 14 , at $338,343$.

101 Lipson, op. cit. supra note 1, at 302; Leet of Nedham and Monecroft (1300) reported in Hudson, Leet Jurisdiction in Nomvich (Selden Society, - 1892) 52; Riley, Memorials of London (1868); see Butlond v. Austen (1507) Select Cases in the Star Chamber (Selden Society, 1902) 262, 267.

${ }^{102}$ Lipson, op. cit. supra note 1, at 314; Unwin, The Gilds and Companies of London (1908) 92. 
of the fishmongers in London. ${ }^{103}$ So strong were some of the gilds that in London, for example, the fishmongers at various times controlled the common council and elected a member as mayor of the city. ${ }^{10 x}$ As early as 1321 the monopoly of the weavers' gild was the subject of complaint. ${ }^{105}$ IIembership in the gilds was the chief way of securing citizenship, and for this reason the gilds often acquired control of the city government.:03 Intrenched in their control of local governments, they soon developed abuses. Obstacles were placed in the way of securing membership. Foreigners were rigorously excluded. Admission fees were made prohibitive so as to limit competition and prevent the workers from themselves engaging in the trade. Thus in 1536 we find a statute reciting that the "fellowship of crafts have by cautel and subtle means" caused "divers apprentices to be sworn upon the holy Evangelist at their first entry that they $* \because \quad *$ after their years or terms expired shall not set up or open any shop $\Rightarrow \Rightarrow *$ without the license $\Rightarrow \Rightarrow$ of fellowship of their occupations upon pain of forfeiting their freedom or other like penalty." ${ }^{107}$ Each new member was compelled to feast the entire gild. In 1607 complaint was made that the gild required new members to pay "a great sum of money or make a breakfast, dinner or supper to the whole company, which hath been to the utter undoing of divers young men who have had little store of money to set up their occupation withal." ${ }^{203}$ Expensive liveries were adopted which poorer members could not afford to wear and cliques grew up within the gilds who controlled the organization for the pecuniary benefit of the wealthier members..$^{203}$ The number of apprentices any master could employ was severely limited so as to keep the monopoly of the craft within a few families in the town. ${ }^{110}$ The capitalists emerged from the worliers and formed new organizations under monopolistic grants from the King and became known as the "Livery Companies" because of the ornate and expensive uniforms their members wore. The more powerful gilds backed by wealth and political influence, encroached upon the rights of smaller gilds and sometimes wrecked them. ${ }^{111}$ And as the gilds became exclusive we find them procuring the passage of laws and ordinances making their monopoly more effective and even letters patent from the King ordaining

1031 Riley, op. cit. supra note 78, at 397; Lipson, op. sit. supro note 1, at 337; Welsford, The Strength of Nations (1907) 156, 162, 174, 179.

101 Lipson, op. cit. supra note 1 , at 338.

1054 Rot. Parl. 507; 1 Cunningham, op. cit. supra note 14, at 445.

106 Cunningham, op. cit. supro, note 14, at 340, 884; 1 Ashley, op. cit. supra note 22 , at 89,$103 ; 2$ ibid. 23.

107 (1536) 28 Hen. VIII c. 5.

108 Records of Oxford, 107, cited in Lipson, op. cit. stpres note 1, at 363. 1092 Ashley, op. cit. supra note 22, at 131.

110 Ibid. 91.

111 Ibid. 45. 
that "no one should use that mystery unless he had been admitted by the common consent of the same mystery." ${ }^{112}$ In London the weavers were in the early part of the fourteenth century indicted for restricting output.13 In 1327, complaint was made that the Saddlers "by conspiracy and collusion among themselves have ordained *** that no one of the aforesaid trades shall be so daring as to sell any manner of merchandise that unto their own trade pertains either to freemen of the city or to other persons, but only to themselves in the business of saddlery." 114 In 1435, the ironworkers gild was dissolved because it monopolized the supply and lowered the quality of the iron, to the injury of the other crafts using it. ${ }^{115}$

These abuses aroused the hostility of the common people as well as municipal authorities who were not gild members. No doubt, too, the powers of the gilds aroused the jealousy of the municipal officials for they were in fact exercising quasi-governmental powers. The grant of monopolies of trade to the gilds directly by the King, in various instances, of course, seriously interfered with their control by the towns and created much illwill. 116 The fight between the gilds and the town governments finally ended in triumph for the latter. ${ }^{117}$ In numerous ways officials in different towns adopted varying forms of domestic ordinances regulating the gilds. They elected officers of the gilds. Admission fees were reduced. All rules of the gilds had to be submitted to the town authorities, otherwise they were void and there was no hesitancy in some towns in compelling the amendment or annulment of gild, ordinances. They were denied the right to assess fines or to compel their members to take oaths. In some instances, the gild was abolished or the right to trade opened to non-members. Prices of many commodities were fixed by town authorities or officials. Wages were regulated and the town officials likewise began to set standards of quality.

With the strengthening of the national government its power was likewise directed toward controlling the monopolistic privileges of the gilds. The royal grant of charters interfered seriously with the powers of the towns to regulate these organizations and after widespread agitation an act was passed in 1437 wherein it was recited that the gilds "make themselves many unlawful and unreasonable ordinances $* * *$ for their singular profit

112 Ibid. 77.

1131 Riley, op. cit. supra note 78,416 to 425 ; Lipson, op. sit. supra noto 1 , at 370 .

114 Riley, op. cit. supra note 101, at 157; Lipson, op. cit. supra note 1, at 377.

115 Harris, The Coventry Leet Book (1913) 180; Lipson, op. cit. supra note 1 , at 377 .

1101 Cunningham, op. cit. supra note 14, at 341.

117 See Lipson, op. cit. supra note 1 , at 328 , ff. 
and common damage to the people," and provided that all gild ordinances must be submitted to the justices of the peace or the municipal authorities.11s This act strengthened the regulatory powers of the town. In 1504 another act was enacted with a recital somewhat similar, complaining further of the unreasonable ordinances of the gilds "as well in prices of wares as other things." 119 This act directed that all gild ordinances should be submitted to specified judicial officers, who were in fact officers of the nation and took away from the gilds the power to fix prices. This law was enforced and national regulation was thereby greatly enlarged. The gilds had acquired large funds from members who had left part of their wealth for the saying of masses, and these funds were misused. In 1547 a law was passed confiscating all of the property of the gilds used for religious purposes to be devoted to the erection of schools and providing for the poor,--an action which also no doubt weakened the position of the gilds. ${ }^{220}$ National regulation by destroying the chief function of the gilds greatly contributed to their decay. ${ }^{121}$ In the meantime the heavy burden of maintaining pageants, poor relief and other activities, made membership less attractive. Government control took away many of the powers of the gilds and lessened their power to exact high prices. The exorbitant entrance fees and other unwise regulations forced craftsmen out of the towns into the country and neighboring villages. ${ }^{122}$

Although statutes were enacted to force back trade into the old towns, the movement had gone too far, and henceforth the gild monopolies faced the powerful and uncontrollable competition of innumerable producers whose costs were necessarily lower. Thus the foundations of great free industrial centers like Birmingham and Manchester were laid. The irrestistible development of business organization was forcing a division of trade into separate organizations for manufacture and distribution. The capitalist was becoming an important factor in commerce. The rapid growth of distributors so excited one old writer that he complained that "the breeding of so many merchants in London, risen out of poor mens sons, hath been a marvellous destruction to the whole realm." ${ }^{223}$ The whole policy of legalized monopoly so obviously stifled the development of trade and restricted the opportunity of citizens that the masses of the people grew more and more hostile toward such organizations. Slowly but inexorably during the seventeenth and eighteenth centuries the irresistible force of

118 Ibid. 370.

119 (1503) 19 Henry VII c. 7.

120 (1547) I Edw. VI c. 14.

121 Cunningham, op. cit. supra note 14, at 436.

122 See recital of conditions in (1583) 25 Hen. VIII c. 18; 1 Cunningham, op. cit. supra note 14 , at 518 .

123 Lipson, op. cit. supra note 1 , at 385 . 
competition broke down statutory barriers thus erected by the Crown in the interests of the few, and the gilds lost their monopolies, the one legal privilege to which they clung desperately. In 1549 a law was passed striking at the heart of the gild movement. Aimed particularly at victuallers and cooks, it provided that any such mystery or craft which combined to raise prices should be immediately dissolved, and also prohibited all artisans from fixing prices and in various other ways regulating their trade. ${ }^{221}$ The abuses in the rules governing apprenticeship which were often so designed as to perpetuate the monopoly of trade in privileged families finally compelled the government to destroy the power of the gilds in this respect. ${ }^{125}$

\section{NATIONAL MONOPOLIES BY ROYAL PATENT}

But the people were ultimately confronted with a far greater menace than the sporadic efforts of individuals or gilds in local markets or towns to control prices. ${ }^{12 d}$ With the widening of trade and commerce, Queen Elizabeth saw an opportunity to strengthen and enrich the Crown by national regulation and control of industry. The practice for centuries in granting local monopolies to gilds in the towns was applied in a national way, despite the opposition which was everywhere springing up against the gilds. There had been created by Edward III a few patents, giving foreign workmen exclusive rights to new arts introduced by them. The Queen adopted this policy for a time, issuing patents of monopoly which were in a general way similar to the patents granted by our government. But soon unscrupulous courtiers persuaded her to give them monopolistic rights even over industries already established. The gravest kind of abuses immediately arose. Private business already built up was destroyed, quality was cheapened and citizens everywhere subjected to unreasonable searches and seizures. The monopolists were concerned chiefly with making the largest possible profits out of their monopolies. The persons securing the monopoly of salt at once raised the price from 16 pence to 14 shillings. ${ }^{12 \pi}$ Although there was deep popular dissatisfaction, fear of the power of the Queen prevented effective action. In 1571, a member of the House of Commons, who made complaint of existing evils was censured for his "presumption." But six years later, the opposition in Parliament had become so strong that a bill was introduced which had such support that the Queen was forced to make an

124 (1548) 2 \& 3 Ed. VI c. 15.

125 (1562) 5 Eliz. c. 4.

128 The information contained in this paragraph is largely derived from the following thorough research studies: Price, The English Patents of Monopoly (1913) 1-22; and Gordon, Monopolies by Patent (1897).

127 Morris, Short Inquiry into the Nature of Monopoly and Forestalling (2d ed. 1796) 26. 
appeal to the members, asking them not to "take away her prerogative, which is the chiefest flower of her garden and the principal and head pearl of her crown and diadem." Parliament heeded her request but the Queen did nothing. In 1601, four years later, a bill was introduced, described as, "An exposition of the common law touching those kinds of patents commonly called monopolies." To defeat this bill the Queen was compelled to issue a proclamation in November of this year, in which she revoked the most unpopular patents, acknowledged the right of the courts to determine the lawfulness of the remainder and guaranteed immunity to those who might bring action in the courts of law. The activities of the agents of the patentees seems to have been very high-handed. One member of Parliament spoke of them as "monstrous and unconscionable substitutes to the IIIonopolitans of Starch, Tinn, Fish, Cloth, Oyl, Vinegar, Salt, and I know not what, nay what not? The principallest commodities both of my Town and Country are ingrossed into the hands of these bloodsuckers of the Commonwealth." 1:3

No sooner had the Queen acknowledged the right of her subjects to test the validity of such monopolies in the courts, than a proceeding was brought. Edward Darcy, Esq., Groom of the Privy Chamber of Queen Elizabeth, had been granted the sole right to make playing cards. A London Haberdasher had made and sold a considerable quantity of cards much to Darcy's annoyance, who brought action against him, alleging among other things as a ground for the validity of his patent, that the Queen "intending that her subjects being able men to exercise husbandry should apply themselves thereto and that they should not employ themselves in making playing cards which had not been any ancient manual occupation in this realm, and that by making such a multitude of cards, card playing was become much more frequent and especially among servants and apprentices, and poor artificers; to the end her subjects might apply themselves to more lawful and necessary trades." The case was deemed of such importance, affecting as it did the rights of the Crown, that it was argued three times. Many arguments, sound, fanciful and ridiculous were made, one of them being that "playing cards are but things of vanity and the occasion of loss of time and decrease of substance and causes of want, which is the mother of woe and destruction and therefore it belongs to the Queen,"-which would seem to be rather hard on the Queen. But the court refused to adopt such specious reasoning, holding that while card-playing might be a vanity, "the making of them is neither a vanity or a pleasure but labour and pains." The court held such a monopoly to be void under the common law on the grounds-(a) that all trades furnishing employment to subjects, thus avoiding idleness,

1282 Cunningham, op. cit. supra note-14, at 288. 
are of value to the commonwealth, and an exclusive grant to exercise such a trade is against the liberty and benefit of the subjects; (b) such monopolies are not only prejudicial to the traders excluded but also to the public generally, because their inseparable incidents are (1) the raising of prices, (2) a deterioration in quality and (3) the impoverishment of traders excluded. And with a caution which even a judge was wise to employ in dealing with Queen Elizabeth, the court suavely held that the "Queen was deceived of her grant, for she intended it to be for the public weal, while such a grant is to the prejudice of the public weal." The monopoly was also held to be unlawful on other grounds and contrary to Acts of Parliament. This case, known as the Case of Monopolies, ${ }^{129}$ decided in 1602 , is the great leading case, from which has largely sprung the law condemning restraints of trade. The famous Case of Monopolies did not settle the great constitutional battle between the Throne and Parliament concerning the power of the Crown to grant trade monopolies. At first James I, who succeeded Queen Elizabeth, showed a disposition to comply with the decision of the court and in 1603 issued a proclamation revoking several patents which Elizabeth "at the importunitie of her servants, whom she was willing to reward with little burden to her estate (otherwise by necessary occasions exhausted)" had granted. ${ }^{130}$ But the King soon yielded to the importunities of his courtiers, granting to them such privileges, with the result that Parliament again discussed the abuses in 1606. The pressure exerted on the King resulted in the issuance by him in 1610 of a quaint book, known as the Book of Bounty wherein he listed a number" of things as to which he saw fit to "expressly command that no suitor presume to move Us." 131 Three years later a court boldly held that no man could be prohibited from working in his lawful trade because the common law abhors idleness and therefore "abhors all monopolies which prohibit any man from working in his lawful trade." ${ }^{132}$ But the King soon forgot his word and granted new patents with serious economic results. The patent granted for dressing and dyeing cloth, for example, threw the whole trade into confusion, and reacted severely on the weavers. $^{133}$ By 1621 there was agitation in Parliament for the enactment of a law against such monopolies. Proponents of legislation prohibiting monopolies had to act warily in encroaching on the King's rights, so they hit upon the happy expedient of drawing up a statute containing verbatim a considerable part of the King's language appearing in his Book of Bounty. ${ }^{134}$ In 1624,

129 (1602) 11 Coke, *84 B.

1302 Cunningham, op. cit. supra note 14, at 288.

131 For a facsimile copy of this book see Gordon, op. cit. supros note 126.

132 Ipswich Taylors Case (1614) 11 Coke, *53a.

1332 Cunningham, op. cit. supra note 14, at 294.

134 Gordon, op. cit. supra note 126 , at 2,8 . 
this Iaw, known as the Statute of MIonopolies, was enacted. It declared monopolies to be contrary to the law, provided that the validity of all patents be determined according to common law practice, but excepted patents granted for new inventions. $2=5$ But existing monopolies still retained the powerful support of the King.

The development of corporate organizations which permitted groups of traders to write in a single organization and procure a patent monopoly from the King greatly accentuated the evils of existing monopolies. Finally, after continuous struggle between Charles I and Parliament, the Long Parliament in 1610 cancelled a number of monopolies, thus directly usurping what was deemed to be a right of the King. ${ }^{130}$ From this time on monopolies and combinations in restraint of domestic trade had no further support from the government.

\section{THE FOREIGN TRADE MIONOPOLIES}

During the early middle ages, foreign trade was carried on under great difficulties. Pirates and robbers infested trade routes. Government in many countries was weak and could give little protection to foreigners. Consular organizations did not exist to protect the rights of their countrymen. The individual trader who ventured into foreign lands risked not only his property but also his life. It was therefore but natural that men who desired to engage in such a trade should organize themselves in bodies for their common protection while in foreign countries. And following the general practice then common of procuring monopolistic grants from the Crown, they secured from the King so-called grants or patents giving them such exclusive rights to trade in specified territory or countries. The earliest of these organizations formed at the beginning of the fourteenth century was the Mierchants of the Staple. The staple was the export depot through which all wool and similar merchandise exported had to pass, and the Merchant Staplers at different times secured a monopoly of this traffic. ${ }^{137}$ Later there developed the poweriul and picturesque organizations aptly named the Merchant Adventurers. These companies of Merchant Adventurers in the larger cities became very influential organizations closely united, and they often lent great aid to the Crown in its foreign relations. ${ }^{138}$ Later the Levant Company, The Royal African Company, The East India Company, The Hudson Bay Company, The Muscovy Company and others, secured for themselves the sole right to trade in great sections of the world. Some of these com-

135 Price, op. cit. supra note 126 , at 34 .

136 Ibid. 46.

$13 \pi$ Lipson, op. cit. supra note 1 , at 471 .

138 Ibid. 474. 
panies were called regulated companies; others were joint stock companies. The regulated companies, while given monopolies of trade, were much like the modern trade association, their individual members trading on their own capital but subject to the rules prescribed by the company. Thus, although holding a monopoly, there was leeway for competition between the members if the rules permitted it. Membership was originally intended to be freely open to any trader who desired to join, the original purpose of the organizations being mutual protection and orderly controlled trade. The joint stock companies were much like our modern corporations, the capital being united and the company trading as a single business unit. Its monopoly, so far as Inglish competition was concerned, was therefore theoretically complete. To these great trade organizations the far flung development of the British Empire is in no small degree attributable. They exercised functions of the government in territories where no real government existed, supporting forts, soldiers and administrative officials. They were able to secure many privileges from governments, which would have been beyond the reach of the single trader. They regulated the quality of the articles exported to a considerable extent. They fixed minimum prices at a high level which members were not permitted to cut, forbade secret trading, compelled a division of trade among the members and protected the person and property of their members against violence and extortion. ${ }^{133}$ In dealing with uncivilized communities some such organization was essential.

But soon agitation began to arise against the abuses resulting from their monopoly. In $\mathbf{1 5 5 0}$ we find clothiers complaining that the Merchant Adventurers "by agreement set such a price upon their cloths that without the loss of twenty shillings in a piece, they could not utter them." ${ }^{140}$ Again in 1604 we read in the Journals of the House of Commons of the price-fixing activities of this organization.141 "The clothiers," runs the complaint, "having no utterance of their cloth but to the Merchant Adventurers, they by complot among themselves will buy at what time, what quantity and what price, themselves list: whereby the clothiers are fain often to return with loss, to lay their cloths to pawn, to stock their trade- to the utter ruin of their poor workmen with their wives and children." The monopoly of trade to foreign countries likewise sometimes gave to such companies a monopoly of the products of such countries for importation into England. The House of Commons report in 1604 in denouncing the Muscovy Company which monopolized the trade to and from Russia said, "This is a strong and shameful monopoly, a monopoly in a

139 Ibid. 491; 1 Cunningham, op. cit. supra note 14, at 220.

140 Acts of the Privy Council (1550-1552) 19, cited in Lipson, op. cit. supra note 1 , at 428.

1411 Cunningham, op. cit. supra note 14, at 218. 
monopoly, both abroad and at home, a whole Company by this means, is become as one man, who alone hath the uttering of all the Commodities of so great a country." 142 In 1604 complaint was made in the House of Commons of "the engrossing and restraint of trade" of such companies by a coterie of London merchants. But a bill designed in part to abrogate "those orders in Companies which tend to MTonopoly" which was introduced in the House of Commons was successfully devitalized by the House of Lords.143 A few more years experience, however, proved the necessity of regulation and the King in 1622 issued a proclamation which required all ordinances of such companies to be submitted to the Privy Council. This proclamation read:

"And whereas a suspition hath been raised upon the Societies and Companyes of the Mierchant Adventurers and other Merehants, and of some Companyes of Handicrafts Mien, that for their private Gains and particular Advantage they make and put in Execution divers Ordinances amongst themselves for ordering their Trades and Mysteries, which tend to the hurt of the publique, we will and command you, and hereby give you Power and Authoritie, uppon any Complaint to be made unto you thereof, to enform yourselves of the Ordinances, Orders and Constitutions of such Companyes and Societies of Merchants and others for the ordering of their Trade, to the end that if it shall appeare that any thing therein contayned be unfitt to be contynued, as tending to the generall hurt of others, either in the making of Cloth, or otherMerchandize and Wares of this Kingdome over deare or otherwise, that the same may be laid down, and that no new Orders or Ordinances be hereafter made and executed by the said Companyes or any of them, before they be first perused and allowed by Us and our Privie Councell, or so many of them as we shall thereunto especially appoint." 14

In 1642 the monopolistic restrictions were removed and foreign trade made free to all Englishmen.145 Evincing some of the eriticisms of the times is this excerpt from an old pamphlet published in 1645 which claims that the patent of monopolies given to the Mierchant Adventurers-

"trencheth upon the native Rights of the freeborn subject: which Patent hath been often complained of and clamored against from time to time, as an universall greevance to Town and Countrey, tending to the diminution of Trade, and of all sorts of Mianufactures at home and to the disrepute of the policy of this Nation abroad, the sayd Patent being accounted no lesse amongst all people, then a Monopoly, a word odious all the world over:" 14 s

But the experiment was premature and after a few years experience the rights of the companies were re-established.

142 Ibid. 220.

143 1 Journals of The House of Commons (1604) 219.

1s: 17 Rymer Foedera (1869) 413; 1 Cunningham, op. cit. supie note 14, at 217.

145 1 Cunningham, op. cit. supra note 14, at 218.

146 $A$ Discourse consisting of Motizes for Enlargcment and Frecdonse of 
The record of the 17th century is a record of continuous complaint against the practices of these monopolies. It was charged that they refused to meet the price competition of their foreign competitors, particularly the French, thus letting them secure the major portion of the trade to the harm of English workmen and producers. ${ }^{147}$ It was claimed that they favored the products of one section of the country over another. ${ }^{148}$ Their exorbitant fees for membership adopted for the purpose of excluding traders and keeping the membership limited, compelled the government to take action to reduce them.149 There was also, of course, bitter opposition to such companies by independent traders, who endeavored with increasing success to encroach upon the rights of the monopolistic companies, such as the East India Company, which were given political and judicial power and did not hesitate to inflict the severest kind of penalties on competitors in their territory who came within their power. ${ }^{150}$ The East India Company lilrewise spent large sums for the corruption of public officers. Even in an age when corruption of public servants was somewhat common, its activities created a national scandal. An inquiry by the House of Lords in 1693 developed the fact that this one company had spent $\$ 90,000$ for such purposes, some of which went to the King. ${ }^{151}$ In some instances officials of such companies took advantage of their official positions to carry on a private business of their own at a great profit. ${ }^{162}$ The American colonists who had developed a considerable shipping industry were excluded from this trade and were also hostile.153 It was charged, too, that the companies were inefficient. It was claimed that "Exclusive companies have so many directors, supercargoes, factors, agents, keepers and clerks and these must have so many fees and sweetenings from manufacturers to procure the preference of their goods that it is impossible for them, if they had an inclination to do it, to trade upon an equal footing with private adventurers

Trade *** engrossed by a company of men who stile themsolves Morchant Adventurers. Brit. Mus. 712 g. 16 (2); 1 Cunningham, op. cit. supra note 14 , at 231.

${ }_{147}$ A General Treatise on Naval Trade and Commerce (2d ed. 1753) 32.

148 Reasons humbly offered that Merchant Adventurers are dotrinontal to England and especially to Devonshire. Brit. Mus. $712 \mathrm{~g}, 16$ (8); 1 Cunningham, op. cit. supra note 14, at 232 .

149 (1699) 10 \& 11 Will. III, c. 6; Lipson, op. cit. supra note 1, at 493.

1501 Cunningham, op. cit. supra note 14, at 267; Lipson, op. cit. supro note 1 , at 492 .

1511 Mill, History of British India (3d ed. 1826) 115; 1 Cunningham, op. cit. supra note 14, at 268 .

1521 Cunningham, op. cit. supra note 14 , at 277.

153 Ibid. 271. 
and as they cannot trade so cheap, they must negleet many lesser branches which would turn to good account in the hands of individuals and give bread to thousands." 154

Adam Smith in The Wealth of Nations charged that such monopolies were against the public interest not only because they excluded other Englishmen from the trades, and exacted exorbitant prices but also were guilty of extraordinary waste and fraud..$^{155}$ The resentment against and opposition to such organizations steadily increased and one by one they lost their exclusive privileges, although one, The Hudson Bay Company, retained its monopolistic rights until 1869.150 When government was weak and foreign trade perilous, the great companies were well nigh essential organizations in the great pioneer work of developing foreign trade and as instruments through which the gorernment could in a measure regulate export commerce. But with the strengthening of governments the world over, with the establishment of world-wide consular systems and the establishment of law and order in most parts of the world, this need largely passed for international commerce and the rights of aliens could be more fairly regulated and protected by treaties between sovereign nations. The corruption of the government, the inefficiency, the denial of the right of free men to engage freely in foreign trade, the obvious harm to the national interests in the curtailment of the expansion of world trade which resulted in restricting the free play of individual initiative and enterprise, and other evils which flowed from such monopolies created a popular hostility which made their abolition inevitable and in the latter part of the eighteenth century these great organizations were shorn of their powers and monopolistic privileges.

In the latter years of the eighteenth century there developed a spirit of individualism which shattered the monopolistic system and revolutionized the relations between government and industry. With the purpose of fostering trade the government, as has been shown, enacted the most stringent laws against forestalling of local markets. It had granted monopolies to the gilds, patent monopolies of domestie trade to individuals, monopolies of foreign trade to great trading companies, and through protective tariffs, navigation acts and minute regulations, had protected the domestic trader against foreign competition. For several hundred years the opposition to such an artificial control of trade had grown more intense. Now a new development added tremendous force to the opposition. The industrial revolution, resulting from an amazing development of machinery in manufacture had produced great manufacturers of powerful influence. Their greatly

154 Op. cit. supra note 147 , at 33 .

1552 Smith, op. cit. supra note 67, Book iv, chap. vii, Part iii.

1501 Cunningham, op. cit. supra note 14 , at 279 . 
increased production not only had to reach national markets but also the markets of the world. Local laws restricting the free movement of goods, gild monopolies, tariffs which brought about foreign discriminations, all aroused their hostility. They became powerful proponents of laissez-faire policies, and individualism. ${ }^{10}$ They were hostile to the merchants and small manufacturers who clung to the monopolistic ideas. Economists, such as Adam Smith, condemned both the "wretched spirit of monopoly" and "the sophistry of merchants inspired by the spirit of monopoly." ${ }^{158}$ The cumulative force of all these divergent interests forced the abolition of monopoly and the establishment of a government policy designed to secure freedom of trade to every English citizen.

Thus through the centuries the policy of legalized monopoly was adopted in England in one form after another only to be forced out of existence as the masses of men became free and the power of government passed to the people. Monopolies of the markets, the towns, the nation and of foreign trade were all discarded upon the insistence of the people who demanded freedom of trade in order that every individual should have opportunity to win the commercial success to which his initiative and ability entitled him, and that the trade of the country might expand under the stimulus flowing from the ambitious competition of the freemen of a great nation. So that by the time the American colonies became a free and independent nation, the irresistible expansion of trade had largely wrecked the paternalistic control of industry by government and was ushering in a great new era of unrestricted individualism and free competition.

(To be continued)

157 Bowden, Industrial Society in England towards the End of the Eighteenth Century (1925) 193.

1582 Smith, op. cit. supra note at 67 , Book iv, chap. ii. 